\title{
Effect of nitrogen loading rate and alkalinity on partial nitritation in a continuous stirred tank reactor
}

\author{
Daehee Choi ${ }^{1}$, Thanh Phuong To ${ }^{1}$, Wonsang Yun ${ }^{1}$, Dongjin $\mathrm{Ju}^{2}$, Keugtae $\mathrm{Kim}^{3}$, Jinyoung Jung ${ }^{{ }^{\dagger}}$ \\ ${ }^{1}$ Department of Environmental Engineering, Yeungnam University, Gyeongbuk 38541, South Korea \\ ${ }^{2}$ Samjin precision co. Ltd. 132-gil, Daehwa-ro, Daedeok-gu, Daejeon, South Korea \\ ${ }^{3}$ Department of Environmental \& Energy Engineering, Suwon University, 17 Wauan-gil, Gyeonggi-do, South Korea
}

\begin{abstract}
In order to achieve an appropriate effluent ratio of ammonium and nitrite as an influent of the anaerobic ammonium oxidation process, the optimum conditions for the partial nitritation in a continuous stirred tank reactor (CSTR) were investigated using real reject water. Hydraulic retention time (HRT) and influent alkalinity $\left(\mathrm{HCO}_{3}{ }^{-}\right) / \mathrm{NH}_{4}{ }^{+}-\mathrm{N}$ ratio were major factors that greatly influenced the partial nitritation. As a result of continuous operation, ammonium conversion efficiency (ACE) and effluent nitrite to ammonium ratio (NAR) could be achieved at the HRT of $19 \mathrm{~h}$ corresponding to $0.71 \mathrm{~kg} / \mathrm{m}^{3} / \mathrm{d}$ of nitrogen loading rate (NLR). Thereafter, the influent $\mathrm{HCO}_{3}{ }^{-} / \mathrm{NH}_{4}{ }^{+}-\mathrm{N}$ ratio was adjusted from 0.5 to 2 , and as a result, the optimum partial nitritation efficiency was maintained when the influent $\mathrm{HCO}_{3}{ }^{-} / \mathrm{NH}_{4}{ }^{+}-\mathrm{N}$ ratio was one. The suitability of the determined operating conditions was verified in a CSTR over $30 \mathrm{~d}$ of operation time.
\end{abstract}

Keywords: $\mathrm{AOB}, \mathrm{HCO}_{3}{ }^{-} / \mathrm{NH}_{4}{ }^{+}-\mathrm{N}$ ratio, NLR, NOB, Partial nitritation

\section{Introduction}

Conventional ammonia nitrogen removal is based on autotrophic nitrification and heterotrophic denitrification [1-5]. In aerobic nitrification, ammonia is oxidized to nitrate by two different groups of bacteria. The first group, ammonia-oxidizing bacteria (AOB), converts ammonia to nitrite. In this reaction, each one mole of ammonium oxidation consumes 2 moles alkalinity theoretically, according to the nitritation chemical equation [6]. Then, the second group, nitrite-oxidizing bacteria (NOB), further oxidizes the intermediate product to nitrate $[7,8]$. The relevant reactions are presented in Eq. (1) and Eq. (2). In the anoxic denitrification (Eq. (3)), nitrate and nitrite are converted to gaseous nitrogen by denitrifiers that is accomplished with a variety of external carbon source such as methanol, acetate, ethanol, and lactate [9]. Recently, the limitations of high oxygen requirement for nitrification and an external carbon source for denitrification is being the driving forces for developing new low-cost biological treatment processes for complete nitrogen removal $[10,11]$.
$\mathrm{NH}_{4}+1.5 \mathrm{O}_{2} \rightarrow \mathrm{NO}_{2}^{-}+2 \mathrm{H}^{+}+\mathrm{H}_{2} \mathrm{O}$

(AOB: Ammonia-oxidizing bacteria)

$$
\mathrm{NO}_{2}^{-}+0.5 \mathrm{O}_{2} \rightarrow \mathrm{NO}_{3}^{-}
$$

(NOB: Nitrite-oxidizing bacteria)

$6 \mathrm{NO}_{3}^{-}+5 \mathrm{CH}_{3} \mathrm{OH}+\mathrm{H}_{2} \mathrm{CO}_{3} \rightarrow 3 \mathrm{~N}_{2}+6 \mathrm{HCO}_{3}^{-}+8 \mathrm{H}_{2} \mathrm{O}(3)$

Novel nitrogen removal process via a newly discovered ANAMMOX (ANaerobic AMMonium OXidation) process has been recognized as a promising cost-effective and low energy alternative to conventional processes due to a significant reduction of aeration and alkalinity for nitrification and organic carbon for denitrification [7, 12-15]. In the ANAMMOX process, the planctomycete-like bacteria oxidize ammonium and nitrite simultaneously to nitrogen gas under the anoxic condition as shown in Eq. (4).

$$
\begin{gathered}
\mathrm{NH}_{4}^{+}+1.32 \mathrm{NO}_{2}^{-}+0.066 \mathrm{HCO}_{3}^{-}+0.13 \mathrm{H}^{+} \rightarrow \\
\mathrm{N}_{2}+0.26 \mathrm{NO}_{3}^{-}+0.066 \mathrm{CH}_{2} \mathrm{O}_{0.5} \mathrm{~N}_{0.15}+2 \mathrm{H}_{2} \mathrm{O} \\
\mathrm{NH}_{4}^{+}+\mathrm{HCO}_{3}^{-}+0.75 \mathrm{O}_{2} \rightarrow \\
0.5 \mathrm{NH}_{4}^{+}+0.5 \mathrm{NO}_{2}^{-}+\mathrm{CO}_{2}+1.5 \mathrm{H}_{2} \mathrm{O}
\end{gathered}
$$

This is an Open Access article distributed under the terms of the Creative Commons Attribution Non-Commercial License (http://creativecommons.org/licenses/by-nc/3.0/) which permits unrestricted non-commercial use, distribution, and reproduction in any medium, provided the original work is properly cited.

Copyright (C) 2022 Korean Society of Environmental Engineers
Received October 15, 2020 Accepted January 06, 2021

$\dagger$ Corresponding author

E-mail: jinjung@ynu.ac.kr

Tel: +82-53-810-2541 Fax: +82-53-810-4624

ORCID: 0000-0002-2150-6698 
To achieve an appropriate ratio to ammonium and nitrite for ANAMMOX process, PN (Partial Nitritation) is an essential process as shown in Eq. (5). In theory, the substrate ratio of $\mathrm{NO}_{2}{ }^{-} / \mathrm{NH}_{4}{ }^{+}$for ANAMMOX bacteria is 1.32:1 [16]. However, considering the high toxicity to ANAMMOX bacteria of $\mathrm{NO}_{2}^{-}$ over $\mathrm{NH}_{4}{ }^{+}$, the ratio of $\mathrm{NO}_{2}{ }^{-} / \mathrm{NH}_{4}{ }^{+}$ratio was recommended as 1:1 [17]. This ratio can maintain the highest specific ANAMMOX activity (SAA) which is $0.32 \mathrm{gN}_{2} / \mathrm{gVSS} / \mathrm{d}$ during continuous operation [18].

To achieve successful PN, the following conditions must be considered. Firstly, NOB should be suppressed [19]. The following factors are considered as operating parameters for this: dissolved oxygen (DO), temperature, $\mathrm{pH}$, free ammonia (FA), and free nitrous acid (FNA) [20-22]. Secondly, the appropriate ammonium oxidation efficiency for the subsequent ANAMMOX process should be controlled, resulting in $\mathrm{NO}_{2}{ }^{-} / \mathrm{NH}_{4}{ }^{+}$ratio $=1$. AOB requires approximately two moles of $\mathrm{HCO}_{3}{ }^{-}$per mole of $\mathrm{NH}_{4}{ }^{+}$ while NOB requires a lower amount of alkalinity [23]. Therefore, moles of alkalinity per mole of $\mathrm{NH}_{4}{ }^{+}$consumed in nitrification or nitritation would be closely related to ammonium oxidation efficiency.

In this study, a whole cell entrapment technique was applied to inhibit the selective activity of NOB, which was demonstrated in previous studies [24]. On the other hand, the operating parameters for controlling ammonium oxidation efficiency have not been investigated, considering the properties of bacteria immobilized in PVA. Therefore, in order to control the ammonium oxidation efficiency in the nitritation reactor, hydraulic retention time (HRT) and influent alkalinity concentration were considered as the main variables, and the operation efficiency for each variable was evaluated.

\section{Materials and Methods}

\subsection{Whole Cell Entrapment Procedure}

The solution containing $15.0 \%$ (w/v) of polyvinyl alcohol (PVA) and $2.0 \%(\mathrm{w} / \mathrm{v})$ of sodium alginate (SA) was autoclaved at $121^{\circ} \mathrm{C}$ for $20 \mathrm{~min}$. After cooling to room temperature, the concentrated activated sludge was mixed with PVA/alginate solution. This solution mixture was dropped into a solution of saturated $\mathrm{H}_{3} \mathrm{BO}_{3}$ and $\mathrm{CaCl}_{2}$ to form spherical carriers. The carriers were kept in the $\mathrm{H}_{3} \mathrm{BO}_{3}$ and $\mathrm{CaCl}_{2}$ solution for $2 \mathrm{~h}$, then immersed in a 0.5 $\mathrm{M}$ orthophosphate solution $\left(\mathrm{KH}_{2} \mathrm{PO}_{4}\right)$ for $1 \mathrm{~h}$, and finally washed with distilled water.

\subsection{Experiment Set-Up}

As shown in Table 1, the PN was carried out in an aerated and continuous stirred tank reactor (CSTR) that had a working volume of $1.74 \mathrm{~L}$. A raw reject water, which consisting of $\mathrm{NH}_{4}{ }^{+} \mathrm{N}(680$ $\pm 120 \mathrm{mg} / \mathrm{L}$ )as the main substrate was taken from the wastewater treatment plant, was used as the feeding for the reactor. Other influent charateristics were as follows; $\mathrm{pH} 8.1 \pm 0.2$, alkalinity $2,430 \pm 415 \mathrm{mg} \mathrm{CaCO}_{3} / \mathrm{L}, \mathrm{BOD} 125 \pm 23 \mathrm{mg} / \mathrm{L}, \mathrm{NO}_{2}{ }^{-}-\mathrm{N} 0.1 \pm$ $0.1 \mathrm{mg} / \mathrm{L}$ and $\mathrm{NO}_{3}{ }^{-}-\mathrm{N} 0.7 \pm 0.6 \mathrm{mg} / \mathrm{L}$. Because of the low growth rate of $\mathrm{AOB}$, this study used PVA/alginate beads with a $300 \mathrm{~mL}$
Table 1. Operation Conditions

\begin{tabular}{lc}
\hline Conditions & \\
$\mathrm{NH}_{4}{ }^{+}-\mathrm{N}(\mathrm{mg} / \mathrm{L})$ & $680 \pm 120$ \\
$\mathrm{BOD} / \mathrm{NH}_{4}{ }^{+}-\mathrm{N}$ ratio & $0.2 \pm 0.05$ \\
Alkalinity $\left(\mathrm{mgCaCO}_{3} / \mathrm{L}\right)$ & $2,430 \pm 415$ \\
Temperature $\left({ }^{\circ} \mathrm{C}\right)$ & $30 \pm 2$ \\
Air flow rate $(\mathrm{L} / \mathrm{min})$ & 3 \\
Working volume $(\mathrm{L})$ & 1.74 \\
PVA/alginate beads size $(\mathrm{mm})$ & $3.34 \pm 0.3$ \\
HRT (h) & $12,15,19$ \\
\hline
\end{tabular}

volume (packing ratio of $17.2 \%$ ). In the reactor, aeration was conducted by an air diffuser stone, and DO concentration was controlled around 3.5-4 mg/L during the experiment. The temperature was maintained at $30 \pm 2{ }^{\circ} \mathrm{C}$ in the temperature room. The $\mathrm{pH}$ was not controlled.

\subsection{Operation Conditions}

The experiments in this study were split into 4 period: In period 1 , the CSTR reactor was started by gradually increasing $\mathrm{NH}_{4}{ }^{+}-\mathrm{N}$ concentration from $200 \mathrm{mgN} / \mathrm{L}$ to $400 \mathrm{mgN} / \mathrm{L}$ (tap water was used for dilution) at HRT $12 \mathrm{~h}$ for $40 \mathrm{~d}$. In period 2, Raw reject water was fed, at different HRT 12, 15 and then $19 \mathrm{~h}$ for 25, 24, and 29 d, respectively. In period 3, the influence of alkalinity on PN was evaluated by changing the $\mathrm{HCO}_{3}{ }^{-} / \mathrm{NH}_{4}{ }^{+}$ratios from $0.5: 1,1: 1$, 1.5:1, and 2:1 for $15 \mathrm{~d}$ at HRT $19 \mathrm{~h}$. In period 4, verification of optimum conditions for the stable $\mathrm{PN}$ by maintaining the $\mathrm{HCO}_{3}{ }^{-} / \mathrm{NH}_{4}{ }^{+}$ratios at 1:1 and HRT $19 \mathrm{~h}$ for $30 \mathrm{~d}$.

\subsection{Analytical Methods}

To monitor the PN performance in the reactor, alkalinity and the concentration of $\mathrm{NH}_{4}{ }^{+}-\mathrm{N}, \mathrm{NO}_{2}{ }^{-}-\mathrm{N}$, and $\mathrm{NO}_{3}{ }^{-} \mathrm{-N}$ in influent and effluent were routinely measured according to Standard methods [25]. The analytical methods are summarized in Table 2.

Table 2. Analytical Methods of Operation Factors

\begin{tabular}{lc}
\hline Factors & Analytical methods \\
$\mathrm{NH}_{4}{ }^{+}-\mathrm{N}$ & Kjeldahl nitrogen analysis \\
$\mathrm{NO}_{2}{ }^{-} \mathrm{-N}$ & Colorimetric method \\
& Ion Chromatography \\
$\mathrm{NO}_{3}{ }^{-}-\mathrm{N}$ & (Dionex $\mathrm{DX}$ 500/High pressure liquid \\
& chromatography) \\
Alkalinity & Titration method \\
& Periodic measurement \\
DO & (D-55, Horiba Ltd, Kyoto, Japan) \\
& Periodic measurement \\
pH, temperature & (F-51, Horiba Ltd, Kyoto, Japan)
\end{tabular}




\section{Results and Discussion}

\subsection{Adaptation of Bacteria to New Operation Conditions}

During the adaptable period, the CSTR was operated at constant HRT $12 \mathrm{~h}$ when NLR was increased from 0.42 to $0.84 \mathrm{kgN} / \mathrm{m}^{3} / \mathrm{d}$ by increasing the influent $\mathrm{NH}_{4}{ }^{+}-\mathrm{N}$ concentration gradually from 200 to $400 \mathrm{mg} / \mathrm{L}$. Fig. 1 represented the evaluation of the PN during this period. Despite the high influent ammonium concentration, a stable ammonium conversion efficiency (ACE) was reached about $50.2 \pm 0.5 \%$ and the detective nitrate concentration was lower than $3 \mathrm{mg} / \mathrm{L}$. In the PN process with the wastewater containing a high concentration of nitrogen, a strategy for controlling DO concentration is most commonly used as a method of selectively inhibiting NOB. Its concentration is reported to be less than 0.5 $\mathrm{mg} / \mathrm{L}$ [26]. Considering this, whole cell entrapment is a very effective technique. Even if DO concentration in the bulk phase is maintained high, the DO concentration diffused into the carrier is very rapidly limited. This is a mechanism for selective inhibition of NOB [27]. This has already been verified in many studies [28, 29].

Nitrite production rate of $0.21 \pm 0.02 \mathrm{kgN} / \mathrm{m}^{3} / \mathrm{d}$ was achieved at $0.42 \mathrm{kgN} / \mathrm{m}^{3} / \mathrm{d}$ of $\mathrm{NLR}$ and reached $0.43 \pm 0.02 \mathrm{kgN} / \mathrm{m}^{3} / \mathrm{d}$ at $0.84 \mathrm{kgN} / \mathrm{m}^{3} / \mathrm{d}$ of NLR. It meant that half of influent ammonium was converted to nitrite nitrogen. And an effluent nitrite to ammonium ratio (NAR) of one was achieved during the majority of period. In the beginning, bacteria quickly adapted to new operative conditions for $40 \mathrm{~d}$ by maintaining HRT at $12 \mathrm{~h}$.

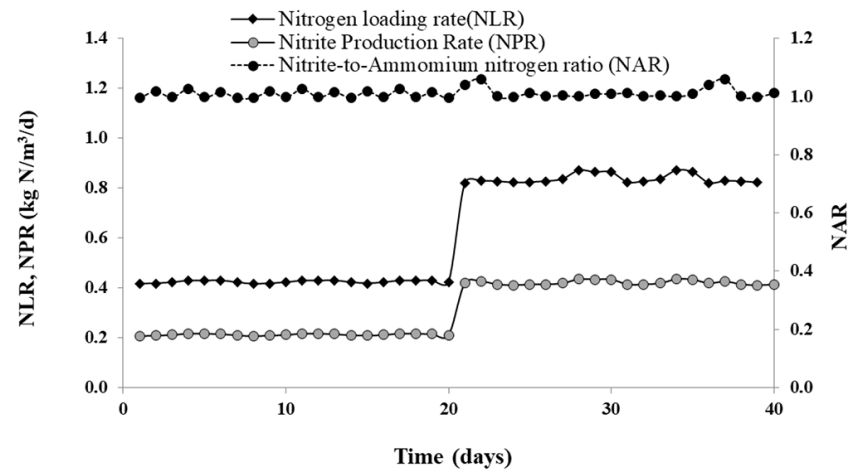

Fig. 1. The nitrogen loading rate (NLR), nitrite produced rate (NPR) and nitrite-to-ammonium nitrogen ratio (NAR) in the CSTR during adaptable section.

\subsection{Effect of NLR on Partial Nitritation}

After the previous adaptation, the CSTR was operated for $68 \mathrm{~d}$ using reject water (without dilution), which was studied at different HRT of 12, 15, and $19 \mathrm{~h}$. The influent ammonium concentration was around $680 \pm 120 \mathrm{mg} / \mathrm{L}$. The NLR gradually increased with decreasing the HRT and the effect of NLR on PN was presented in Fig. 2. The results showed that the ACE and the effluent NAR were well correlated to the HRT. At the HRT $12 \mathrm{~h}, 45.1 \pm 0.42 \%$ of influent $\mathrm{NH}_{4}{ }^{+}-\mathrm{N}$ was oxidized to $\mathrm{NO}_{2}{ }^{-}-\mathrm{N}$, resulting in NAR of $0.8 \pm 0.05$. At the HRT $15 \mathrm{~h}$, ACE showed $49.1 \pm 0.11 \%$ and NAR was $0.93 \pm 0.03$. ACE presented $51.9 \%$ and NAR was 1.03 \pm 0.03 at $19 \mathrm{~h}$ of HRT. Moreover, effluent nitrogen speciation

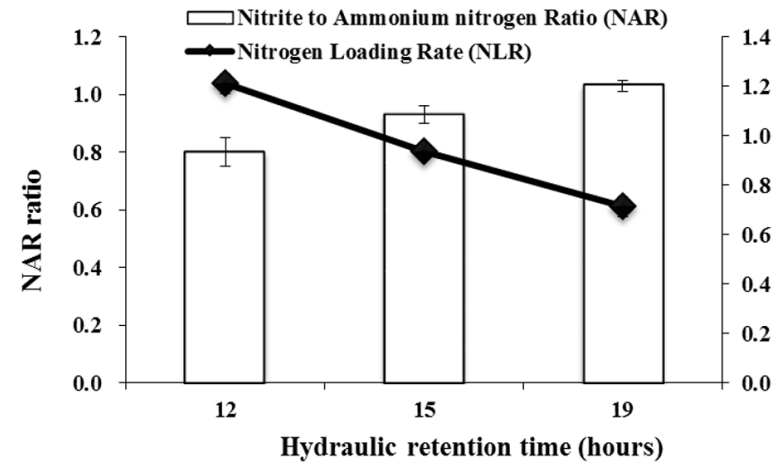

Fig. 2. Effect of nitrogen loading rate (NLR) on partial nitritation at different hydraulic retention time (HRT).

was mainly composed of ammonium and nitrite in an equimolar ratio, resulting in nitrate concentration lower than $4 \mathrm{mgNO}_{3}^{-}-\mathrm{N} / \mathrm{L}$. Consequently, suitable HRT for the PN was 19 hours, corresponding to $0.71 \mathrm{kgN} / \mathrm{m}^{3} / \mathrm{d}$ of the NLR. It could be concluded that the HRT posed a significant effect on the PN in the CSTR.

\subsection{Effect of influent alkalinity on partial nitritation}

For stable nitrogen removal in the ANAMMOX process suppression of complete nitrification in the PN is essential [30, 31]. In addition, an appropriate is required [32, 33]. In this study, not only the accumulation of nitrate in the PN reactor was effectively suppressed by utilizing the characteristics of PVA/alginate bead, but also the NAR control factor according to the influent nitrogen load fluctuation was investigated. Among them, the effect of HRT in the PN reactor with PVA/alginate beads was verified in this study.

As shown in Fig. 3, the influence of alkalinity on PN was evaluated by changing the $\mathrm{HCO}_{3}{ }^{-} / \mathrm{NH}_{4}{ }^{+}$ratios from 0.5 to $1,1.5$, and 2 . The influent $\mathrm{pH}$ was maintained at $7.7 \pm 0.6$. At $\mathrm{HCO}_{3}{ }^{-} / \mathrm{NH}_{4}{ }^{+}-\mathrm{N}$ ratio of 1 , the ACE showed $51 \pm 0.52 \%$ as well as nitrite accumulation efficiency (NAE) represented $50.3 \pm 0.53 \%$. By adding sodium bicarbonate to increase $\mathrm{HCO}_{3}{ }^{-} / \mathrm{NH}_{4}{ }^{+}$ratio to 1.5, the ACE and NAE increased to $60 \pm 1.56 \%$ and $59.4 \pm 1.5 \%$, respectively. In the case of the influent $\mathrm{HCO}_{3}{ }^{-} / \mathrm{NH}_{4}{ }^{+}$ratio of 2 , the ACE of $72 \pm 1.19 \%$ and the NAE of $71.6 \pm 1.1 \%$ were achieved. However, at a condition

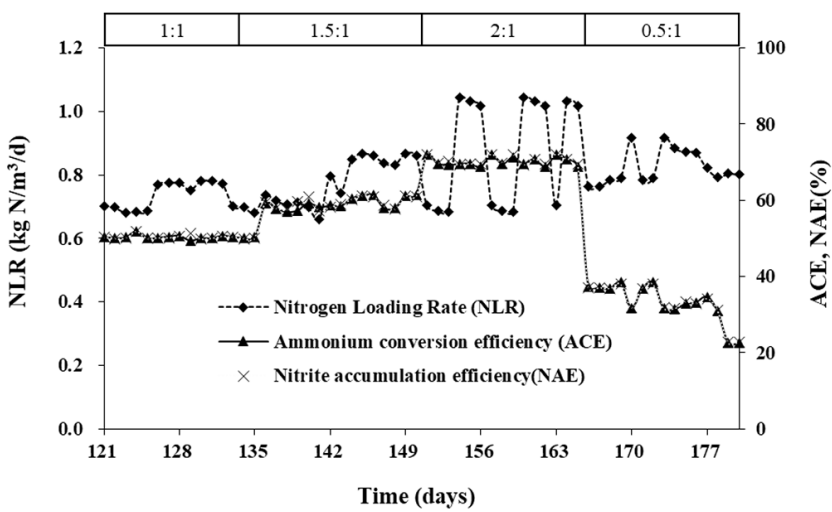

Fig. 3. Change of ammonium conversion efficiency (ACE) and nitrite accumulation efficiency (NAE) at different alkalinity conditions. 
where influent $\mathrm{HCO}_{3}{ }^{-} / \mathrm{NH}_{4}{ }^{+}$ratio was 0.5 , not only ACE but also NAE dropped to $33 \pm 5.0 \%$ and $33.1 \pm 4.89 \%$, respectively, although the effluent $\mathrm{pH}$ remained relatively constant at $6.8 \pm 0.2$.

Alkalinity plays two functions for AOB which are the carbon source for AOB and the acidification buffer for the hydrogen ion produced by ammonia oxidation [34, 35]. Only approximately $10 \%$ of inorganic carbon is assimilated into bacteria, and the majority of the $\mathrm{HCO}_{3}{ }^{-}$is utilized to neutralize hydrogen ion [23]. Although the mechanisms are not clear yet, many researchers emphasized the role of $\mathrm{HCO}_{3}^{-}$to effectively achieve $\mathrm{PN}$, and influent $\mathrm{HCO}_{3}{ }^{-} / \mathrm{NH}_{4}{ }^{+}-\mathrm{N}$ was considered as a representative operating factor [22, 36, 37]. In this study, influent wastewater characteristic with the $\mathrm{HCO}_{3}{ }^{-} / \mathrm{NH}_{4}{ }^{+}$ratio of 1 was suitable for PN-ANAMMOX system without external alkalinity.

\subsection{Implications of Operating Parameters for Partial Nitritation}

In this study, the PN was achieved under the conditions where the HRT was $19 \mathrm{~h}$ corresponding with $0.71 \mathrm{kgN} / \mathrm{m}^{3} / \mathrm{d}$ of NLR. In addition, when the influent $\mathrm{HCO}_{3}{ }^{-} / \mathrm{NH}_{4}{ }^{+}-\mathrm{N}$ ratio was $1: 1$, the most effective partial nitritation efficiency was shown. In general, the raw reject water has a property of $\mathrm{HCO}_{3}{ }^{-} / \mathrm{NH}_{4}{ }^{+}-\mathrm{N}$ ratio of $1: 1$, which leads to the advantage of biological treatment by the ANAMMOX/PN process. However, when $\mathrm{CO}_{2}$ stripping that consumes alkalinity in the reactor [38] and denitrification reaction that generates alkalinity [39] react as the same time, separate operating factors should be studied to maintain about $50 \%$ of ACE.

\section{Conclusions}

In summary, the PN was carried out in the CSTR treating raw reject wastewater. PVA/alginate beads were used to inhibit NOB activity selectively, and $\mathrm{NLR}$ and influent $\mathrm{HCO}_{3}{ }^{-} / \mathrm{NH}_{4}{ }^{+}-\mathrm{N}$ ratio were considered as the major operating parameters for $\mathrm{PN}$.

PN reactor was operated in a CSTR at HRT of $19 \mathrm{~h}$ corresponding with $0.71 \mathrm{kgN} / \mathrm{m}^{3} / \mathrm{d}$ of NLR. Under these conditions $51.9 \pm 0.14 \%$ of ACE and $1.03 \pm 0.03$ of NAR could be achieved. At $\mathrm{HCO}_{3}{ }^{-} / \mathrm{NH}_{4}{ }^{+} \mathrm{N}$ ratio of $1: 1$, ACE showed $51 \pm 0.52 \%$ as well as NAR was 1.01 \pm 0.01 , which was appropriate to the requirements of subsequent ANAMMOX process. The determined operating parameters were verified through continuous operation over $30 \mathrm{~d}$.

\section{Acknowledgements}

This project is supported by Korea Ministry of Environment as “Global Top Project”(Project No: 2019002190001)

\section{Author Contribution}

D.C. (Ph.D.) designed all experiments and wrote the manuscript. T.T. (Undergraduate student) and W.Y. (Ph.D. student) conducted all the experiments. D.J. (Ph.D.) and K.K. (Professor) supported writing manuscript. J.J. (Professor) revised and reviewed the manuscript.

\section{Reference}

1. Collivignarelli C, Bertanza G. Simultaneous nitrification-denitrification processes in activated sludge plants: Performance and applicability. Water Sci. Technol. 1999;40:187-194.

2. Lan CJ, Kumar M, Wang CC, Lin J-G. Development of simultaneous partial nitrification, anammox and denitrification (SNAD) process in a sequential batch reactor. Bioresour. Technol. 2011;102:5514-5519.

3. Honga M, Yunb Y-M, Leea T-J, et al. Denitrification performance and microbial community variation during reverse osmosis concentrate treatment by sulfur denitrification process. Desalin. Water Treat. 2020;183:54-65.

4. Qambrani NA, Jung SH, Ok YS, Kim YS, Oh S-E. Nitrate-contaminated groundwater remediation by combined autotrophic and heterotrophic denitrification for sulfate and $\mathrm{pH}$ control: batch tests. Environ. Sci. Pollut. Res. 2013;20:9084-9091.

5. Choi M, Park J, Yoon S, et al. Enhanced denitrification of contaminated groundwater by novel bimetallic catalysts supported on kaolin-derived zeolite: effects of natural dissolved inorganic and organic matter. Environ. Sci. Nano 2020;7(12):3956-3978.

6. Szatkowska B, Plaza E, Trela J, Hultman B, Bosander J. Combined partial nitritation and Anammox biofilm system as a sustainable solution for supernatant treatment. Water Practice Technol. 2007;2(1):wpt2007005.

7. Choi Dh, Cho Sh, Jung Jy. Key operating parameters affecting nitrogen removal rate in single-stage deammonification. Chemosphere 2018;207:357-364.

8. Choi D, Lee C, Jung J. Innovative start-up strategies for single-stage deammonification with conventional activated sludge: Results of a pilot-scale demonstration. Bioresour. Technol. 2020;123423.

9. Jung S, Kim Y, Kang H. Denitrification rates and their controlling factors in streams of the Han River Basin with different land-use patterns. Pedosphere 2014;24:516-528.

10. Choi Dh, Cho Kj, Jung Jy. Optimization of nitrogen removal performance in a single-stage SBR based on partial nitritation and ANAMMOX. Water Res. 2019;162:105-114.

11. Jetten MSM, Schmid M, Schmidt I, et al. Improved nitrogen removal by application of new nitrogen-cycle bacteria. Rev. Environ. Sci. Biotechnol. 2002;1:51-63.

12. Bae Hk, Chung YC, Jung JY. Microbial community structure and occurrence of diverse autotrophic ammonium oxidizing microorganisms in the anammox process. Water Sci. Technol. 2010;61:2723-2732.

13. Cho Kg, Choi Mk, Jeong Dw, Lee Sk, Bae Hk. Comparison of inoculum sources for long-term process performance and fate of ANAMMOX bacteria niche in poly (vinyl alcohol)/sodium alginate gel beads. Chemosphere 2017;185:394-402.

14. Choi D, Lee D, Yun W, Jung J. Addition of a foaming agent to improve N2 gas permeability of PVA/alginate carriers for deammonification process. Int. J. Hydrogen Energy 2017;42: 27812-27819.

15. Choi Dh, Lee Cw, Jung Jy. Innovative start-up strategies for single-stage deammonification with conventional activated sludge: Results of a pilot-scale demonstration. Bioresour. Technol. 2020;123423. 
16. Choi J, Jung S, Ahn Y-H. Increased hydrazine during partial nitritation process in upflow air-lift reactor fed with supernatant of anaerobic digester effluent. Korean J. Chem. Eng. 2013;30: 1235-1240.

17. Tomar S, Gupta SK, Mishra BK. Performance evaluation of the anammox hybrid reactor seeded with mixed inoculum sludge. Environ. Technol. 2016;37:1065-1076.

18. Lee H, Kim I, Jung J, Kim J. Determination of the Optimum NH4+-N/NO2--N Ratio by Anaerobic Batch Test in Anaerobic Ammonium Oxidation Process. J. Korean Soc. Environ. Eng. 2008;30:700-704.

19. Lotti T, Kleerebezem R, Hu Z, et al. Simultaneous partial nitritation and anammox at low temperature with granular sludge. Water Res. 2014;66:111-121.

20. Li H, Zhou S, Huang G, Xu B. Achieving stable partial nitritation using endpoint $\mathrm{pH}$ control in an SBR treating landfill leachate. Process Saf. Environ. Prot. 2014;92:199-205.

21. Liang Z, Han Z, Yang S, et al. A control strategy of partial nitritation in a fixed bed bioflim reactor. Bioresour. Technol. 2011;102:710-715.

22. Gabarró J, Ganigué R, Gich F, et al. Effect of temperature on AOB activity of a partial nitritation SBR treating landfill leachate with extremely high nitrogen concentration. Bioresource Technol. 2012;126:283-289.

23. Bae Hk, Yang Hj, Chung Yc, Yoo YJ, Lee Sk. High-rate partial nitritation using porous poly (vinyl alcohol) sponge. Bioprocess Biosyst. Eng. 2014;37:1115-1125.

24. Choi Dh, Khan MH, Jung Jy. Crosslinking of PVA/alginate carriers by glutaraldehyde with improved mechanical strength and enhanced inhibition of deammonification sludge. Int. Biodeterior. Biodegrad. 2019;145:104788.

25. APHA A. Wpcf. Standard Methods for the Examination of Water and Wastewater. $20^{\text {th }}$ ed. Washington, D.C.: Amer Public Health Assn; 1998.

26. Wang X, Gao D. In-situ restoration of one-stage partial nitritation-anammox process deteriorated by nitrate build-up via elevated substrate levels. Scientific Reports 2016;6:37500.

27. Chou W-P, Tseng S-K, Ho C-M, et al. Highly efficient partial nitrification by polyvinyl alcohol-alginate immobilized cells. J. Chin. Inst. Eng. 2012;35:793-801.

28. Minh NT, Choi M, Park N, et al. Critical design factors for polyvinyl alcohol hydrogel entrapping ammonia-oxidizing bacteria: biomass loading, distribution of dissolved oxygen, and bacterial liability. Environ. Eng. Res. 2020;26.

29. Isaka K, Itokawa H, Kimura Y, Noto K, Murakami T. Novel autotrophic nitrogen removal system using gel entrapment technology. Bioresour. Technol. 2011;102:7720-7726.

30. Li J, Zhang L, Peng Y, et al. NOB suppression in partial nitritation-anammox (PNA) process by discharging aged flocs: Performance and microbial community dynamics. Chemosphere 2019;227:26-33.

31. Arriagada C, Guzmán-Fierro V, Giustinianovich E, et al. NOB suppression and adaptation strategies in the partial nitrification -Anammox process for a poultry manure anaerobic digester. Process Biochem. 2017;58:258-265.

32. Lackner S, Gilbert EM, Vlaeminck SE, et al. Full-scale partial nitritation/anammox experiences-an application survey. Water Res. 2014;55:292-303.

33. Mampaey KE, De Kreuk MK, van Dongen UG, van Loosdrecht $\mathrm{MC}$, Volcke EI. Identifying N2O formation and emissions from a full-scale partial nitritation reactor. Water Res. 2016;88: 575-585.

34. Wen J, Tao W. Biological Nitrogen Removal in Biofilters Enhancing Nitritation-Anammox Process: Considerations of Design Parameters. In: American Soceity of Agricultural and Biological Engineers Annual International Meeting 2012, ASABE 2012; July 29-Aug 1 2012; Dallas, Texas. 2012.

35. Bagchi S, Biswas R, Nandy T. Alkalinity and dissolved oxygen as controlling parameters for ammonia removal through partia nitritation and ANAMMOX in a single-stage bioreactor. J. Ind Microbiol. Biotechnol. 2010;37:871-876.

36. Ganigué R, Volcke E, Puig S, Balaguer MD, Colprim J. Impact of influent characteristics on a partial nitritation SBR treating high nitrogen loaded wastewater. Bioresour. Technol. 2012;111: 62-69.

37. Fux C, Boehler M, Huber P, Brunner I, Siegrist H. Biological treatment of ammonium-rich wastewater by partial nitritation and subsequent anaerobic ammonium oxidation (anammox) in a pilot plant. J. Biotechnol. 2002;99:295-306.

38. He K, Lv T, Wu S, et al. Treatment of alkaline stripped effluent in aerated constructed wetlands: feasibility evaluation and performance enhancement. Water 2016;8:386.

39. Elefsiniotis P, Li D. The effect of temperature and carbon source on denitrification using volatile fatty acids. Biochem. Eng. J. 2006;28:148-155 